\title{
KLAUZULE GENERALNE I ZASADY SŁUSZNOŚCI
}

\section{Wstęp}

Orzekanie na zasadach słuszności należy odróżnić od orzekania przy zastosowaniu klauzul generalnych. Klauzule generalne są szczególnymi przepisami prawnymi, stanowiącymi część systemu prawnego. Stany faktyczne danej sprawy oceniane są na podstawie zasad słuszności. W szczególności do klauzul generalnych zaliczamy: zasady współżycia społecznego, dobre obyczaje, dobrą wiarę oraz zasady słuszności - czyli normy i wartości pozaprawne. Wobec tego przyjąć należy, iż klauzule generalne spełniają funkcję uzupełniającą i definiującą w stosunku do przepisów prawa. W przypadku zasad słuszności sąd nie odwołuje się do panującego zwyczaju, ale przyjmuje w danej sprawie określone rozwiązanie, które jest słuszne, sprawiedliwe. Orzekanie na zasadach słuszności polega na rozwiązaniu sporu zgodnie z zasadami słuszności i sprawiedliwości, niezależnie od przepisów prawnych, a nawet wbrew ich dyspozycjom. ${ }^{1}$ Czy wobec tego, stosowanie w rozstrzygnięciach jako podstawy zasad słuszności może prowadzić do nadużycia? Doktryna prawnicza w powyższej materii ukształtowała dwie koncepcje nadużycia prawa, zwane teoriami zewnętrzną i wewnętrzną. Teoria zewnętrzna uznaje, że nadużycie prawa jest działaniem nieakceptowanym z uwagi na cele, ale jest działaniem w ramach prawa. Uprawniony jest niejako napiętnowany przez pobudki lub cel, podejmowanych czynności, jednakże wykonuje swoje uprawnienia w ramach systemu prawa. Teoria wewnętrzna uznaje, że ten, kto wykonuje swoje prawo podmiotowe w sposób spełniający określone kryteria (np. zła wiara, naruszenie interesów innego podmiotu), nadużywa swego prawa i wykracza w ten sposób poza system prawa. Teoria ta przyjmuje zatem, że nadużycie prawa jest działaniem bezprawnym. Według niektórych autorów, w tym uję-

1 A. Lizer-Klatka, Pojęcie orzekania na zasadach słuszności w międzynarodowym arbitrażu handlowym, „Państwo i Prawo" 2000, z. 1, s. 61. 
ciu istnieją problemy natury terminologicznej. Nie może bowiem nadużywać prawa ktoś, kto go nie posiada. ${ }^{2}$

Klauzulą generalną nazywa się zwykle zawarty w przepisie prawnym zwrot niedookreślony, oznaczający pewne oceny (niekiedy wskazywane pośrednio przez wartości, do których oceny te są zrelatywizowane lub też przez uzasadnione tymi ocenami normy) funkcjonujące w jakiejś grupie społecznej, będące jednak poza systemem prawnym. Skutek zamieszczenia w przepisie klauzuli generalnej polega na tym, że oceny, wartości czy normy oznaczone przez klauzulę muszą być uwzględnione przez organ stosujący prawo przy ustalaniu stanu faktycznego i wyznaczaniu jego konsekwencji prawnych. ${ }^{3}$

Przepisy prawa cywilnego materialnego wielokrotnie odwołują się do zasad współżycia społecznego. W związku z tym wyodrębnia się trzy grupy takich przepisów. ${ }^{4}$ Przepisy, w których naruszenie zasad współżycia społecznego wywołuje ujemne skutki prawne dla naruszającego. Wskazać tu należy: art. 5 k.c. o bezprawności używania prawa, sprzecznego z zasadami współżycia społecznego, art. $58 \S 2$ k.c. o nieważności czynności prawnej, sprzecznej z zasadami współżycia społecznego, art. 94 k.c. dotyczący fikcji warunku rozwiązującego sprzecznego z zasadami współżycia społecznego, art. $354 \S 1$ k.c. ustanawiający granice swobody umów.

Do drugiej grupy zaliczamy przepisy, w których powstanie, zmiana lub ustanie praw czy obowiązków, zależą od ich oceny w świetle zasad współżycia społecznego. Przykladowo powołać można: art. 3571 i art. 3581 § 3 k.c. zezwalające na sądową zmianę lub rozwiązanie umowy lub waloryzację świadczenia zgodnie z zasadami współżycia społecznego w przypadku nadzwyczajnej zmiany stosunków, art. 411 pkt 2 k.c., wyłączający roszczenie $\mathrm{z}$ tytułu nienależnego świadczenia, odpowiadającego zasadom współżycia społecznego, art. 902 k.c. wyłączający możliwość odwołania darowizny, która czyni obowiązkowi, wynikającemu z zasad współżycia społecznego. Do kolejnej grupy zaliczyć można te przepisy, które korzystają z pojęcia zasad współżycia społecznego w celu sprecyzowania treści stosunku prawnego. Przykładowo są to: art. 56 k.c., według którego skutki czynności prawnej wynikają nie tylko z treści czynności prawnej, ale także z zasad współżycia społecznego, art. 65 k.c. ustalający zasady współżycia społecznego jako jedno z kryteriów wykładni oświadczeń woli, art. 140 i art. 233 k.c., według których zakres uprawnień właściciela, użytkownika wieczystego i uprawnionego z tytułu służebności gruntowej lub osobistej określają także zasady współżycia społecznego. ${ }^{5}$

Klauzule generalne mają przede wszystkim za zadanie zapewnić zgodność norm prawnych i opartych na tych normach rozstrzygnięć indywidualnych $\mathrm{z}$ obo-

\footnotetext{
2 T. Bukowski, Klauzule generalne w prawie cywilnym. O konieczności stworzenia katalogu zasad współżycia społecznego, „Monitor Prawniczy” 2008, nr 24.

Powtarzam za: P. Machnikowski, Kodeks cywilny. Komentarz, red. E. Gniewek, Warszawa 2013.

Tak: A. Wolter, J. Ignatowicz, K. Stefaniuk, Prawo Cywilne. Zarys części ogólnej, Warszawa 1998, s. 150.

Zob. A. Wolter, Prawo cywilne, Zarys części ogólnej, Warszawa 1977, s. 74 i n.
} 
wiązującymi w społeczeństwie normami pozaprawnymi, zwłaszcza moralnymi. ${ }^{6}$ Klauzule generalne jako, że spełniają funkcję uzupełniającą i definiującą w stosunku do przepisów prawa - odsyłają do rodzajowo określonych ocen i norm pozaprawnych. Oznacza to, że podmiot stosujący normy nie znajduje bezpośrednich podstaw oceniania $\mathrm{w}$ systemie prawnym i odwołuje się do ukształtowanych $\mathrm{w}$ danym środowisku ocen społecznych. Oceny i normy moralne wskazywane w klauzulach generalnych nie stanowią źródła prawa i nie stanowią samoistnej podstawy normatywnej kwalifikacji stanów faktycznych. Klauzule generalne uzyskują znaczenie prawne wtedy, gdy przepis będący źródłem prawa wskazuje je jako wyznaczniki treści normy prawnej.

\section{Zasada współżycia społecznego jako podstawowa klauzula generalna}

Jedną z podstawowych klauzul generalnych stanowią zasady, które są normami społecznymi i które mają zasadnicze znaczenie dla wszystkich stosunków społecznych. Stosowanie zasad współżycia społecznego znajduje skonkretyzowany wyraz w poszczególnych normach prawnych, które odwołują się do tych zasad. ${ }^{7}$ Zgodnie z brzmieniem artykułu 5 kodeksu cywilnego ,nie można czynić ze swego prawa użytku, który by był sprzeczny ze społeczno-gospodarczym przeznaczeniem tego prawa lub z zasadami współżycia społecznego. Takie działanie lub zaniechanie uprawnionego nie jest uważane za wykonywanie prawa i nie korzysta z ochrony". W treści art. 5 k.c. wskazane zostało pojęcie zasad współżycia społecznego. Dyspozycja wskazanego przepisu stanowi, że naruszenie zasad współżycia społecznego jest objęte dezaprobatą, ponieważ wiąże ujemne skutki z takim zachowaniem. Wobec tego wskazane działanie lub zaniechanie prowadzi do nadużycia prawa, ale jest to określenie nieścisłe. Sąd Najwyższy w wyroku z dnia 17 września 1971 r. ${ }^{8}$ orzekł, że sprzeczność z zasadami współżycia społecznego w PRL usprawiedliwiająca zastosowanie art. 5 k.c. nie musi - w świetle tego przepisu - być zawiniona przez stronę i może istnieć nawet $\mathrm{w}$ razie subiektywnie nienagannego jej zachowania się w okresie poprzedzającym wystąpienie tej sprzeczności. Zasady współżycia społecznego w okresie, z którego powołany został powyższy wyrok posiadały charakter norm konstytucyjnych. Artykuł 90 Konstytucji z dnia 22 lipca 1952 r. stanowił, że obywatel jest obowiązany szanować zasady współżycia społecznego.

Zgodnie z uzasadnieniem wyroku Sądu Najwyższego z dnia 26 listopada 2004 r. ${ }^{9}$ przy zastosowaniu art. 5 k.c., konieczne jest wystąpienie następujących przesłanek: istnienie prawa, które zostaje nadużyte, czynienie z niego użytku oraz

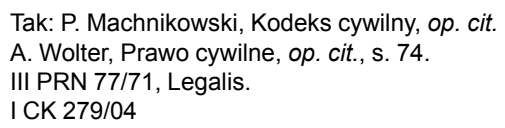


sprzeczność tego użytku z kryteriami nadużycia prawa, w tym sprzeczność z zasadami współżycia społecznego.

W związku z powyższym ewentualna sprzeczność z zasadami współżycia społecznego usprawiedliwiająca zastosowanie art. 5 k.c. nie musi - w świetle tego przepisu być zawiniona przez stronę i może istnieć nawet w razie subiektywnie nienagannego jej zachowania się $\mathrm{w}$ okresie poprzedzającym wystąpienie tej sprzeczności.

Z kolei zgodnie z treścią wyroku Sądu Najwyższego z dnia 22 maja 2003 r., ${ }^{10}$ dla oceny, czy zasady współżycia społecznego uzasadniają w konkretnej sprawie przyznanie odszkodowania, nie bez znaczenia jest również zachowanie się samego poszkodowanego. Powoływanie się w sporze przez strony na naruszenie zasad współżycia społecznego wymaga wskazania, jaka konkretnie zasada została naruszona i jaka jest jej pełna treść. Zakaz nadużycia prawa podmiotowego zawarty w art. 5 k.c. umożliwia korygowanie obowiązującego prawa przedmiotowego zgodnie ze standardami wyznaczonymi przez społeczne wartości i normy moralne. Zgodnie z utrwalonym w tym zakresie orzecznictwem Sądu Najwyższego, art. 5 k.c. może być zastosowany tylko po wykazaniu wyjątkowych okoliczności. ${ }^{11}$ Sąd Najwyższy wskazał, że zasadniczą kwestią stosowania art. 5 k.c., w cytowanym wyżej orzeczeniu, jest możliwość stosowania art. 5 k.c., nawet jeśli działanie podmiotu sprzeczne z zasadami współżycia społecznego nie wiąże się jednocześnie z negatywną oceną zachowania tego podmiotu.

Klauzula generalna w postaci zasad współżycia społecznego powinna być traktowana jako immanentny czynnik wszelkiego zachowania się. Natomiast brzmienie art. 5 nie daje podstaw do dokonania jakichkolwiek wyłączeń w zakresie stosowania zawartej w nim normy, która powinna być wzięta pod uwagę przy rozstrzyganiu każdej sprawy. ${ }^{12}$ Jak wskazał Sąd Najwyższy w tezie wyroku z dnia 20 października $2011 \mathrm{r}^{13}$ ocena, czy w rozpoznawanym przypadku zachodzi podstawa do zastosowania art. 5 k.c. wymaga analizy całokształtu okoliczności danej sprawy. Z kolei Sąd Najwyższy w orzeczeniu z dnia 3 lutego 1998 r. ${ }^{14}$ uznał, że: klauzula generalna zawarta $\mathrm{w}$ art. 5 k.c. nie może być rozumiana jako pozostawienie sądowi orzekającemu dowolności w udzielaniu stronie ochrony prawnej lub odmowy takiej ochrony. Na treść zasad współżycia składają się akceptowane i godne ochrony reguły rzetelnego postępowania $\mathrm{w}$ stosunkach społecznych. Wymagają one konkretyzacji w każdej sprawie, w której wchodzi w grę zarzut nadużycia prawa podmiotowego. Stwierdzenie, że strona nadużywa prawa podmiotowego wymaga zatem ustalenia i przytoczenia w uzasadnieniu wyroku tych okoliczności, które pozostają w sprzecz-

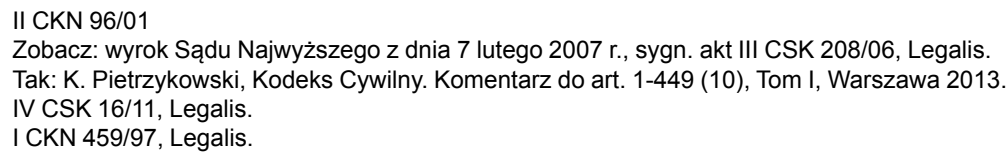


ności z regułami moralnymi wymagającymi przestrzegania. Dopiero wówczas możliwa jest subsumpcja ustalonego stanu pod normę wynikającą $\mathrm{z}$ art. 5 k.c.

Z powyższego wynika, że zasada, która została zamieszczona w art. 5 k.c. posiada charakter wyjątkowy. Oceniając, czy wykonywanie prawa nie narusza zasad współżycia społecznego, należy brać pod uwagę całokształt okoliczności konkretnej sprawy, a nie tylko jedną z tych okoliczności, choćby jej znaczenie było doniosłe. Nie można stosować art. 5 k.c. bez ustalenia okoliczności faktycznych uzasadniających twierdzenie, że określony podmiot nadużywa swojego prawa podmiotowego.

W orzecznictwie Sądu Najwyższego ugruntowała się tzw. zasada „czystych rąk” polegająca na tym, że na zasady współżycia społecznego może powołać się tylko ten, kto sam swego prawa nie nadużywa. Zgodnie z tezą wyroku Sądu Najwyższego $\mathrm{z}$ dnia 25 sierpnia $2011 \mathrm{r}^{15}$ : odmowa udzielenia ochrony prawnej na podstawie art. 5 k.c., ze względu na jego wyjątkowy charakter musi być uzasadniona istnieniem okoliczności rażących i nieakceptowanych w świetle powszechnie uznawanych w społeczeństwie wartości. ${ }^{16}$

Podmiot, który korzysta z prawa podmiotowego postępuje zgodnie z zasadami współżycia społecznego - jest to domniemanie prawne, na podstawie którego stwierdzić można, że ciężar dowodu istnienia okoliczności faktycznych uzasadniających ten zarzut spoczywa na tym, kto podnosi taki zarzut. Sąd zobowiązany jest dokonywać oceny w toku przeprowadzania postępowania dowodowego, czy korzystanie przez konkretny podmiot $\mathrm{z}$ przysługującego mu prawa nie stanowi nadużycia prawa. ${ }^{17}$ Zgodnie z poglądem Sądu Najwyższego, wyrażonym w wyroku z dnia 7 grudnia $1965 \mathrm{r}^{18}$ : domniemanie przemawia za tym, że ten kto korzysta ze swego prawa, czyni to w sposób zgodny z zasadami współżycia społecznego. Dopiero istnienie szczególnych okoliczności może domniemanie to obalić i pozwolić na zakwalifikowanie określonego zachowania jako nadużycie prawa, nie zasługującego na poparcie z punktu widzenia zasad współżycia społecznego.

Sąd Najwyższy w wyroku z dnia 29 listopada 2002 r. ${ }^{19}$ stwierdził jednoznacznie, że: dopuszczalność realizacji roszczeń odszkodowawczych współwłaścicieli wobec zarządcy wyłącza możliwość skutecznej ich obrony zarzutem nadużycia prawa podmiotowego przeciw roszczeniom dochodzonym. W myśl utrwalonej wykładni, art. 5 k.c. może być stosowany, gdy w innej drodze nie można zabezpieczyć interesu osoby zagrożonej wykonaniem prawa podmiotowego drugiej osoby.

W postępowaniu arbitrażowym rozstrzygnięcie sporu na podstawie ogólnych zasad prawa lub zasad słuszności następuje tylko w przypadku wyraźnego upoważ-

\footnotetext{
15 II CSK 640/10, Legalis.

16 Zob. również np: wyrok SN z dnia 9 marca 1972 r. III CRN 566/71; wyrok SN z dnia 4 stycznia 1979 r. III CRN 273/78, Legalis.

17 S. Dmowski, Komentarz do Kodeksu Cywilnego, Księga pierwsza. Część ogólna, Warszawa 2001, s. 29.

18 III CR 278/65, Legalis.

19 IV CKN 1549/00, Legalis.
} 
nienia stron. Zgodnie z treścią art. $1194 \S 1$ k.p.c., sąd polubowny rozstrzyga spór według prawa właściwego dla danego stosunku, a gdy strony go do tego wyraźnie upoważniły - według zasad prawa lub zasad słuszności. W powołanym przepisie ustawodawca odwołuje się do zasad słuszności w tekście prawnym, jako do czynnika wskazującego na metodę rozwiązania sporu. Chociaż w każdym przypadku sąd musi przestrzegać podstawowych zasad prawa.

W teorii znaczenie zasad słuszności oznacza istnienie pewnego systemu reguł słuszności, ze względu na które sędzia dokonuje oceny konkretnej sprawy. W praktyce nie można przyjąć założenia, że orzekanie na podstawie zasad słuszności nie ma znaczenia, bowiem może być to treść nawet abstrakcyjna. Orzekanie przez sądy na zasadach słuszności jako podstawy rozstrzygania sporów, rodzi potrzebę rozróżnienia tych zasad od klauzul generalnych, które odsyłają do zasad i pojęcia słuszności. Celem klauzul generalnych jest odwoływanie się w rozstrzygnięciach do kryteriów pozostających poza systemem prawnym, ponadto klauzule generalne pozwalają na stosowanie w rozstrzygnięciach sporów kryteriów oceniających. Orzekanie na zasadach słuszności polega na poszukiwaniu rozwiązania istniejącego sporu zgodnie z dyrektywami słuszności i sprawiedliwości, w sposób, w który są one rozumiane przez sędziów oraz niezależnie od obowiązujących norm prawnych. ${ }^{20}$

Sąd stosując zasady słuszności, jako podstawę rozstrzygania sporu, powinien mieć na względzie, że zasady te pozostają w nierozerwalnym związku z całokształtem okoliczności danej sprawy i w ten sposób wyznaczają podstawy rozstrzygnięcia danego sporu. Sąd orzekając według zasad słuszności, musi brać pod uwagę podstawowe zasady porządku prawnego w Rzeczypospolitej Polskiej. Jest to tzw. klauzula porządku publicznego zawarta $\mathrm{w}$ art. 1206 k.p.c. ${ }^{21}$

Powyższe potwierdza utrwalone w praktyce orzecznictwo. Zgodnie $\mathrm{z}$ tezą wyroku Sądu Najwyższego z dnia 8 grudnia 2006 r. ${ }^{22}$ : sąd polubowny przy rozpoznawaniu spraw nie musi - tak jak sąd państwowy - stosować ściśle przepisów prawa materialnego, ale może oprzeć swoje orzeczenie również na zasadach słuszności lub dobrej wiary, a także na określonych zwyczajach. Natomiast Sąd Najwyższy w wyroku z dnia 3 września 2009 r. $^{23}$ stwierdził, że: naruszenie przez sąd polubowny prawa materialnego właściwego dla rozstrzyganego stosunku - którego przestrzeganie, co do zasady, nakazuje art. $1194 \S 1$ k.p.c. - uzasadnia uchylenie wyroku tego sądu jedynie wtedy, gdy łączy się z pogwałceniem podstawowych zasad porządku prawnego (art. $1206 \S 2$ pkt 2 k.p.c.).

Z kolei ustawodawca $\mathrm{w}$ treści art. $417^{2}$ k.p.c. odsyła do zasad słuszności, bowiem zgodnie $\mathrm{z}$ jego brzmieniem: jeżeli przez zgodne $\mathrm{z}$ prawem wykonywanie władzy publicznej została wyrządzona szkoda na osobie, poszkodowany może żądać

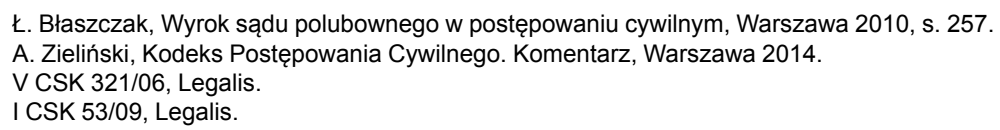


całkowitego lub częściowego jej naprawienia oraz zadośćuczynienia pieniężnego za doznaną krzywdę, gdy okoliczności, a zwłaszcza niezdolność poszkodowanego do pracy lub jego ciężkie położenie materialne, wskazują, że wymagają tego względy słuszności.

Powyższe uregulowanie uwzględnia w swojej treści przyjętą przez Komitet Rady Europy w rekomendacji Nr R/84/15 z dnia 18 września 1984 r. w sprawie odpowiedzialności władzy publicznej - zasadę, która zakłada możliwość przyznania odszkodowania także wówczas, gdy nie można władzy publicznej zarzucić uchybienia, jednakże ze względu na podjęcie czynności w interesie ogólnym, wyjątkowy charakter szkody i ograniczoną liczbę poszkodowanych, niesłusznym byłoby obciążenie skutkami szkody wyłącznie poszkodowanego. ${ }^{24}$

Powołany powyżej art. $417^{2}$ k.p.c., zawiera roszczenie oparte na zasadzie słuszności, a odejście od przesłanki bezprawności. Roszczenie to daje możliwość naprawienia wyłącznie szkody na osobie wyrządzonej legalnym działaniem władzy publicznej. Konsekwencją tego jest sytuacja, w której odpowiedzialność nie zależy od wykazania adekwatnego związku przyczynowego między działaniem lub zaniechaniem funkcjonariusza a szkodą. Zgodnie z tezą wyroku Sądu Najwyższego z dnia 4 marca $2008 \mathrm{r}^{25}$ : w niektórych przypadkach odpowiedzialności odszkodowawczej, zwłaszcza uzasadnionych zasadami współżycia społecznego (art. 419 k.c.), dopuszczalne jest przyznanie odszkodowania w sytuacji, w której relacji kauzalnej między zdarzeniem szkodzącym a doznanym uszczerbkiem nie da się zakwalifikować jako przyczynowo adekwatnej.

Odnosząc się do zasad współżycia społecznego oraz zasad słuszności, Sąd Najwyższy w wyroku z dnia 22 maja $2003 \mathrm{r}^{26}{ }^{\mathrm{w}}$ tezie stwierdził, że: nie ma podstaw do zasądzenia odszkodowania na podstawie art. 419 k.c., w sytuacji gdy poszkodowany doznał szkody wskutek zgodnej z prawem i niezawinionej interwencji funkcjonariuszy państwowych, jeżeli sam swoim zachowaniem naruszającym zasady współżycia społecznego tę interwencję spowodował.

Sąd Najwyższy uzasadniając powyższą tezę wskazał, że w takiej sytuacji nie można pominąć zachowania się samego poszkodowanego. Jeżeli bowiem sam poszkodowany swoim zachowaniem, naruszającym zasady współżycia społecznego, spowodował konieczność legalnej interwencji i tylko z tej przyczyny, że czynnie jej się przeciwstawiał poniósł szkodę, to nie ma podstaw do kompensacji takiej szkody na zasadzie słuszności. 


\section{Zakończenie}

Klauzule generalne zapewniają elastyczność prawa w różnorodności i zmienności zjawisk społecznych, otwierają system prawa dla wartości powszechnie w społeczeństwie aprobowanych. Dzięki temu mogą zapewnić prawu stanowionemu społeczną aprobatę, zgodną ze standardem oceny wyrażonej w rzymskiej paremii ius est ars boni et aequi. Klauzule generalne powodują otwarcie treści prawa na wartości i oceny pozaprawne, czyli kształtujące się i wyrażane są w życiu społecznym. Wiąże się to z przejściem części odpowiedzialności za spełnianie przez prawo roli środka kontroli społecznej z prawodawcy na praktykę prawniczą.

W polskim systemie prawa klauzula generalna dotycząca zasad współżycia społecznego zajmuje nadrzędną pozycję w stosunku do pozostałych klauzul generalnych. Oznacza to, że spełnia ona rolę wytycznej do stosowania i interpretowania innych klauzul generalnych.

Orzekanie przez Sądy na zasadach prawa i sprawiedliwości to dokonanie oceny słusznościowej według oceny subiektywnej. Zasada słuszności wynika z interpretacji przepisów prawa i wtedy powstaje odpowiedzialność na zasadzie słuszności. Z kolei zasady współżycia społecznego występują fakultatywnie w stosunku do przepisów prawa. Mogą służyć jako miernik zakresu odpowiedzialności, wysokości należnego odszkodowania lub zadośćuczynienia bądź samej podstawy naruszenia. Klauzule generalne wspomagają prawidłowe zastosowanie zasad odpowiedzialności, w szczególności zasad słuszności, które nie mają bezpośredniego związku $\mathrm{z}$ winą sprawcy, ani z dokonanymi przez niego czynnościami. 


\section{GENERAL CLAUSES AND A RIGHTNESS PRINCIPLE}

One should distinguish adjudication on the rightness basis by using general clauses. General clauses are specific principles which constitute part of the legal system. Adjudication on the justice basis is to resolve a dispute in accordance with the principles of justice and fairness, regardless of the legal provisions. The principle of justice stems from interpretation of the law. The rules of social interaction are optional in relation to the law.

Keywords: rules, clauses, standards, justice 